\title{
BLADE ANGLE EFFECT ON DROPLET SIZE SPECTRUM OF ROTARY ATOMIZERS USED IN BRAZIL
}

Doi:http://dx.doi.org/10.1590/1809-4430-Eng.Agric.v36n6p1118-1125/2016

\section{FERNANDO K. CARVALHO ${ }^{*}$, ULISSES R. ANTUNIASSI ${ }^{2}$, RODOLFO G. CHECHETTO ${ }^{3}$, ALISSON A. B. MOTA ${ }^{3}$, GREG R. KRUGER ${ }^{4}$}

\author{
${ }^{1 *}$ Corresponding author. AgroEfetiva/ Botucatu - SP, Brazil. E-mail: fernando@agroefetiva.com.br
}

\begin{abstract}
The effect of blade angle on droplet size spectrum of five rotary cage atomizers and one rotary disc atomizer used in Brazil was evaluated in a high speed wind tunnel, with an air speed of $180 \mathrm{~km} \mathrm{~h}^{-1}$. This study included the characterization of the droplet size spectrum, via laser diffraction instrument, generated by three blades angles, of 45, 60 and 75 degrees. The spray solution was composed of Picoxystrobin + Cyproconazole fungicide (SC), at $20 \mathrm{~mL}$ c.p. $\mathrm{L}^{-1}$, and at a flow rate of $6 \mathrm{~L} \mathrm{~min}^{-1}$. As the angle decreased from 75 to 45 degrees, the rotational speed of the atomizers increased and the volume median diameter (VMD) decreased. However, increasing the rotational speed also increased the percentage of droplets smaller than $100 \mu \mathrm{m}(\%<100 \mu \mathrm{m})$. At the blade angles of 45 and 60 degrees the atomizers showed that $\%<100 \mu \mathrm{m}$ was higher than $20 \%$ and VMD was smaller than $198 \mu \mathrm{m}$. The disc type atomizer resulted in the lower values of relative span (RS). The use of 75 degrees blade angle produced the highest values of VMD and the lowest values of $\%<100 \mu \mathrm{m}$; these parameters were also affected by atomizer model and brand.
\end{abstract}

KEYWORDS: Application technology, atomization, spray drift, pesticides.

\section{INTRODUCTION}

Brazil has the second largest fleet of agricultural aircraft in the world, and rotary atomizer usage for aerial pesticides applications is a very popular practice (BAYER et al., 2011; ANTUNIASSI, 2015). These centrifugal-energy nozzles allow control the droplet size according to its rotational speed, and it is the main factor in influencing the droplet size spectrum (TESKE et al., 2005).

In general, cage or discs rotary atomizers have been used to spray pesticides. The cage type atomizer is constituted of a cylindrical monel metal wire gauze rotating around a fixed hollow spindle (HUANG et al., 2014). The spray solution is released through the hollow spindle and impacts on the cage, resulting in the droplets generation. Thereafter, these droplets also have impact with the air, which also affects the droplets size (TESKE et al., 2005). Cages also can be manufactured with laser designed metal gauze instead of wires. The other type of atomizer is composed of discs with grooves and teeth, by where the liquid is released into the air, also fixed around a hollow spindle (CRAIG et al., 2014).

Blades are used to drive the cage or discs around the spindle. It can be adjusted to select the rotational speed and, consequently, the droplet size. The faster rotation is, the smaller droplets will be produced (TESKE et al., 2005; CRAIG et al., 2014; HUANG et al., 2014).

Droplet size and spray droplet size spectrum are the main factors affecting pesticides efficacy and spray drift. Despite having potential to control insects, diseases and weeds, small droplets are more prone to drift downwind from the application area than larger droplets (ANTUNIASSI et al., 2011; CHECHETTO et al., 2013; GANDOLFO et al., 2014).

The droplet size also affects deposition distance downwind from the sprayed area (CRAIG et al., 2014; FERGUSON et al., 2014). Others parameters that have impact on spray drift are the tank

\footnotetext{
${ }^{2}$ Universidade Estadual Paulista, Faculdade de Ciências Agronômicas (UNESP/FCA)/ Botucatu - SP, Brazil.

${ }^{3}$ AgroEfetiva/ Botucatu - SP, Brazil.

${ }^{4}$ University of Nebraska-Lincoln, West Central Research and Extension Center, North Platte/ United States of America. 
mix, operating pressure, swath width, flight height and weather conditions (HUANG et al., 2012; HILZ \& VERMEER, 2013; FERGUSON et al., 2015).

Examples of aerial spray drift prediction models about drift potential and downwind distance are the AgDRIFT and AgDISP (TESKE et al., 2005; HOFFMANN et al., 2013). These models were created using a database of studies conducted mainly in the USA and Australia (Spray Drift Task Force Database). They promote the adoption of practices to help reduce spray drift during the spray applications of pesticides, increasing environmental protection (FRITZ et al., 2012a).

Despite this scenario, there is lack of information about droplet size spectrum of rotary atomizers that have been used in Brazil (BAYER et al., 2011). Differences in diseases control or spray drift reported in the literature (ANTUNIASSI et al., 2011) may be a consequence of differences between atomizers types and brands.

According to these concerns, the aim of the present study was to characterize the droplet size spectrum of several models of rotary atomizers used in Brazil according to the blade angle, in a high speed wind tunnel.

\section{MATERIAL AND METHODS}

The droplet size spectrum of six rotary atomizers used to spray applications in Brazil was evaluated in a high speed wind tunnel. Five of the atomizers were made by national manufacturers and one of them (ASC-A10) by an international manufacture from the USA. Table 1 gives us details about the treatments abbreviations, atomizer model, blade number, manufacturer, type (disc or cage), as well as the materials used to construct the cages or discs.

TABLE 1. Treatment abbreviation, atomizer model, blade number, manufacturer, atomizer type and cage or disc materials.

\begin{tabular}{|c|c|c|c|c|c|}
\hline $\begin{array}{c}\text { Treatment } \\
\text { abbreviation }\end{array}$ & Atomizer model & $\begin{array}{l}\text { Blades } \\
\text { number }\end{array}$ & Manufacturer & Type & $\begin{array}{c}\text { Cage or disc } \\
\text { Material }\end{array}$ \\
\hline ASC & ASC-A10 & 3 & ASC Rotary Atomizers & Cage & $\begin{array}{l}\text { Laser design } \\
\text { gauze }\end{array}$ \\
\hline CBB & TA-88D-8 & 5 & $\begin{array}{l}\text { Centro Brasileiro de } \\
\text { Bioaeronáutica }\end{array}$ & Discs & Fiberglass \\
\hline Microbell & Microbell & 3 & Microbell & Cage & Wire screen \\
\hline Microspin & Microspin & 3 & Microspin & Cage & Wire screen \\
\hline Stol & Stol & 6 & Stol & Cage & Wire screen \\
\hline Travicar & Travicar 05165 & 3 & Travicar & Cage & $\begin{array}{c}\text { Laser designed } \\
\text { gauze }\end{array}$ \\
\hline
\end{tabular}

All atomizers were set up to apply $6 \mathrm{~L} \mathrm{~min}^{-1}$. The spray solution was composed of water plus the fungicide Aproach $^{\circledR}$ Prima (SC, DuPont ${ }^{\mathrm{TM}}$ ), at $20 \mathrm{~mL}$ c.p. $\mathrm{L}^{-1}$ (Picoxystrobin, $9 \mathrm{~g}$ a.i $\mathrm{L}^{-1}+$ Cyproconazole, $3.6 \mathrm{~g}$ a.i. $\mathrm{L}^{-1}$ ). It was selected this pesticide to adequate the physical-chemical properties of the spray solution according to usual spray applications conducted in Brazil, where the use of fungicides with suspension concentrate formulations are common. There were three repetitions per treatment for all evaluated parameters.

The droplet size measurements were conducted in a high speed wind tunnel, based in a methodology described by FRITZ et al. (2012a). The airspeed of $180 \mathrm{~km} \mathrm{~h}^{-1}(112.5 \mathrm{mph})$ was used for all treatments. It represents the flight speed of the Ipanema airplane, a Brazilian-made aircraft manufactured by Embraer (ANTUNIASSI, 2015).

The study was conducted in the Pesticide Application Technology Laboratory, at the West Central Research and Extension Center of the University of Nebraska-Lincoln in North Platte, Nebraska, USA. The laboratory presented controlled temperature of $20^{\circ} \mathrm{C}\left( \pm 2^{\circ} \mathrm{C}\right)$ and relative humidity of $60-70 \%$. 
The facility contains an opened circuit wind tunnel, with an outlet section of $0.3 \mathrm{~m} \times 0.3 \mathrm{~m}$, capable of producing wind speed up to $300 \mathrm{~km} \mathrm{~h}^{-1}$. The wind tunnel contains a transparent working section (1.2 m height, $1.2 \mathrm{~m}$ width and $6 \mathrm{~m}$ length) in which a mounted spray boom section was used as a supporter to the atomizers. An exhaust air scrubber is used to recover the sprayed pesticides. The wind tunnel is also equipped with a flow straightener to produce laminar air flow through the tunnel working section.

A Sympatec HELOS laser diffraction particle-sizing system (Sympatec Inc., Clausthal, Germany) was used to measure the droplet size spectra downwind of the atomizers, and each replication comprised of operating the atomizers for 10 seconds. It was equipped with a $623 \mathrm{~nm} \mathrm{He}-$ Ne laser and was fitted with a lens (denoted by the manufacturer by R6) able to analyze a range of droplets between $0.5 \mu \mathrm{m}$ and $1750 \mu \mathrm{m}$. The HELOS laser system has an emitter and receiver, which was positioned across from each other and outside of the wind tunnel.

The atomizers were positioned in such way that the center of the spray cloud is crossing the laser beam (TESKE et al., 2001). This configuration was selected because according to these authors, the droplet size changes according to the radial distances from the hub, with the larger droplets going further from the hub and the small droplets keeping closer during the spray applications. The distance from the atomizer to the laser beam was $85 \mathrm{~cm}$, also respecting the parameters proposed by those authors. It was also observed that there were no droplets touching the ceiling, walls or floor of the wind tunnel before crossing the laser.

Three blade angles of 45, 60 and 75 degrees were selected, resulting in different rotational speed (rpm, revolutions per minute). A wide range of other blade angles are available to rotary atomizers, and are usually used from 35 to 80 degrees (HOOPER \& SPURGIN, 1995). The blade angles were adjusted using a protractor and the rotational speed was measured using a laser photo tachometer (Cybertech, DT2234A), while spraying the solution (wet rotation).

The parameters of interest were DV10 $(\mu \mathrm{m}, 10 \%$ of the spray volume consists of droplets with a diameter smaller than the value of DV10); VMD ( $\mu \mathrm{m}$, volume median diameter, $50 \%$ of the spray volume consists of droplets with a diameter smaller than the value of VMD); DV90 ( $\mu \mathrm{m}, 90 \%$ of the spray volume consists of droplets with a diameter smaller than the value of DV90); \%<100 $\mu \mathrm{m}$ (percentage of volume of droplets having a diameter smaller than $100 \mu \mathrm{m}$ ); RS (relative span, this is the difference in diameter for $90 \%$ and $10 \%$ of the spray by volume divided by the VMD) (FERGUSON et al., 2014; AL HEIDARY et al., 2014).

Relative span is a dimensionless parameter indicative of the uniformity of the droplet size distribution, whereas smaller values indicate narrower spectrum (HEWITT, 2007), and \%<100 $\mu \mathrm{m}$ has a positive correlation with the potential risk of spray drift (OLIVEIRA et al. 2015).

The spray category classification values were based on data generated using the guidelines established in ASAE S572.1 "Spray Nozzle Classification by Droplet size spectrum" (ASAE, 2009; FRITZ et al., 2012b). Data generated in this study were analyzed using SAS Enterprise Guide (SAS, Cary, NC, USA). A modified PROC MIXED command was used with replication set as a random factor in analysis. A Tukey's means separation procedure was used to determine statistical significance with $\alpha=0.05$.

\section{RESULTS AND DISCUSSION}

It was observed that increasing the blade angle of the rotary atomizers resulted in slower rotational speed. Although the atomizers were evaluated at the same angles, there were observed differences in the rotational speed between them. It may be resultant of differences such as number of blades, dimension of cage or discs, and material. These results are in accordance with what was described by TESKE et al. (2005).

It was observed that at 45 degrees (Table 2) the ASC atomizer showed the highest value of VMD, $141 \mu \mathrm{m}$, but the value of $\%<100 \mu \mathrm{m}, 31 \%$, was statistically similar to the $\%<100 \mu \mathrm{m}$ observed to the $\mathrm{CBB}$ atomizer, $32 \%$. At the same angle, the Stol and Microbell atomizers resulted 
in the lowest values of VMD, $65 \mu \mathrm{m}$ and $68 \mu \mathrm{m}$, respectively, and the highest values of $\%<100$ $\mu \mathrm{m}, 71 \%$ and $70 \%$, respectively. The other atomizers showed VMD between $106 \mu \mathrm{m}$ and $123 \mu \mathrm{m}$, and $\%<100$ between $32 \%$ and $47 \%$.

TABLE 2. Treatments, atomizer rotational speed (rpm), means of droplet size statistics, percent of droplets smaller than $100 \mu \mathrm{m}$, relative span and droplet size spectrum classification, at the blade angle of 45 degrees. The flow rate and wind speed were $6 \mathrm{~L} \mathrm{~min}^{-1}$ and $180 \mathrm{~km}$ $\mathrm{h}^{-1}$, respectively.

\begin{tabular}{|c|c|c|c|c|c|c|c|c|}
\hline Treatment & $\mathrm{rpm}$ & DV10 & VMD & DV90 & $\%<100 \mu \mathrm{m}$ & $\mathrm{RS}$ & & Category* \\
\hline & & & $-\mu \mathrm{m}$ & & $-\%-$ & & & \\
\hline ASC & 3908 & $54 \mathrm{~A}$ & $141 \mathrm{~A}$ & $276 \mathrm{~A}$ & $31 \mathrm{E}$ & 1.57 & $\mathrm{C}$ & Fine \\
\hline $\mathrm{CBB}$ & 7257 & $52 \mathrm{~A}$ & $123 \mathrm{~B}$ & $189 \mathrm{D}$ & $32 \mathrm{E}$ & 1.12 & $\mathrm{E}$ & Fine \\
\hline Microbell & 3625 & $31 \quad \mathrm{D}$ & $68 \mathrm{D}$ & $157 \mathrm{E}$ & $70 \mathrm{~A}$ & 1.85 & B & Fine \\
\hline Microspin & 4509 & $41 \mathrm{BC}$ & $109 \mathrm{C}$ & $254 \mathrm{~B}$ & $45 \mathrm{C}$ & 1.95 & A & Fine \\
\hline Stol & 6424 & $31 \mathrm{D}$ & $65 \mathrm{D}$ & $149 \mathrm{E}$ & $71 \mathrm{~A}$ & 1.80 & B & Fine \\
\hline Travicar & 4701 & $39 \mathrm{C}$ & $106 \mathrm{C}$ & $196 \mathrm{CD}$ & $47 \mathrm{BC}$ & 1.48 & D & Fine \\
\hline
\end{tabular}

* Category classification values are based on data generated using the guidelines established in ASAE S572.1. Means with the same letters in the column do not differ by Tukey's test at $\alpha=0.05$ level.

Droplets with diameter smaller than $100 \mu \mathrm{m}$ have low sedimentation velocity, about $25 \mathrm{~cm} \mathrm{~s}^{-1}$ (CRAIG et al., 2014). The authors inform that these droplets, despite having potential against pests, are more vulnerable to evaporation, off target movement, and loss to the environment. Droplets bigger than $300 \mu \mathrm{m}$ have high sedimentation velocity, but they are considered too big for the applications of fungicides and insecticides, because of unreasonable coverage on leaves, or are inappropriate to control insects.

With the exception of the CBB atomizer, that showed a relative span of 1.12, all the atomizers had RS above 1.39 at 45 degrees. The RS of the Microspin was the highest, 1.95.

HOOPER \& SPURGIN (1995) observed values of RS to the AU5000 atomizer at a blade angle of 50 degrees, flow rate of $5 \mathrm{~L} \mathrm{~min}^{-1}$, wind speed of $180 \mathrm{~km} \mathrm{~h}^{-1}$ and rotational speed of 5410 $\mathrm{rpm}$, equal to 1.92. At the same conditions, the authors observed that the VMD had changed in between 78 and $92 \mu \mathrm{m}$ when the flow rate was increased from $3.5 \mathrm{~L} \mathrm{~min}^{-1}$ to $5 \mathrm{~L} \mathrm{~min}^{-1}$, respectively, but the observed rotational speed decreased from $5510 \mathrm{rpm}$ to $5410 \mathrm{rpm}$. It was also observed by TESKE et al. (2005) that the flow rate itself did not have a large effect on atomization, while rotational speed and tank mix had a large effect on droplet size.

The lower value of RS observed in the disc atomizer is explained by the process of droplet formation. For discs atomizers it is created by regular ligaments, and there is no impact of the droplet with the cage, resulting in more uniform droplet size, compared to cage atomizers (CRAIG et al., 2014).

The process of droplet formation for cage atomizers is based on the release of droplets through the hollow spindle, that will be broken up by the rotational cage, before having impact with the air (CRAIG et al., 2014). According to the same authors, the disc atomizer has a different mechanism of droplet formation; the liquid is just released through the teeth into the air, in a process known as "ligaments", and does not have impact with the cage.

At 60 degrees (Table 3) the Microspin atomizer showed the highest value of VMD, but not the lowest value of small droplets $(\%<100 \mu \mathrm{m})$. It is explained by the high value of RS, 1.51 . The $\mathrm{CBB}$ atomizer showed VMD of $174.41 \mu \mathrm{m}$, and the lowest values of $\%<100 \mu \mathrm{m}$ and RS, $16.8 \%$ at 1.17, respectively. The other atomizers resulted in values of RS above 1.39. 
TABLE 3. Treatments, atomizer rotational speed (rpm), means of droplet size statistics, percent of droplets smaller than $100 \mu \mathrm{m}$, relative span and droplet size spectrum classification, at the blade angle of 60 degrees. The flow rate and wind speed were $6 \mathrm{~L} \mathrm{~min}^{-1}$ and $180 \mathrm{~km}$ $\mathrm{h}^{-1}$, respectively.

\begin{tabular}{|c|c|c|c|c|c|c|c|}
\hline Treatment & $\mathrm{rpm}$ & DV10 & VMD & DV90 & $\%<100 \mu \mathrm{m}$ & $\mathrm{RS}$ & Category* \\
\hline & & & $-\mu \mathrm{m}-$ & & $-\%$ & & \\
\hline ASC & 3681 & $58 \mathrm{C}$ & $165 \mathrm{C}$ & $288 \mathrm{~B}$ & $24 \mathrm{D}$ & $1.39 \mathrm{E}$ & Fine \\
\hline CBB & 4138 & $73 \mathrm{~A}$ & $174 \mathrm{~B}$ & $276 \mathrm{C}$ & $17 \mathrm{~F}$ & $1.17 \mathrm{~F}$ & Fine \\
\hline Microbell & 3481 & $53 \mathrm{D}$ & $137 \mathrm{DE}$ & $256 \mathrm{D}$ & $32 \mathrm{C}$ & $1.48 \mathrm{CD}$ & Fine \\
\hline Microspin & 2522 & $69 \mathrm{~B}$ & $198 \mathrm{~A}$ & $368 \mathrm{~A}$ & $20 \mathrm{E}$ & $1.51 \mathrm{BC}$ & Fine \\
\hline Stol & 4032 & $44 \mathrm{~F}$ & $103 \mathrm{~F}$ & $203 \mathrm{~F}$ & $48 \mathrm{~A}$ & $1.55 \mathrm{AB}$ & Fine \\
\hline Travicar & 3330 & $49 \mathrm{E}$ & $133 \mathrm{E}$ & $238 \mathrm{E}$ & $34 \mathrm{~B}$ & $1.42 \mathrm{DE}$ & Fine \\
\hline
\end{tabular}

* Category classification values are based on data generated using the guidelines established in ASAE S572.1. Means with the same letters in the column do not differ by Tukey's test at $\alpha=0.05$ level.

At 60 degrees the Stol atomizer showed the lowest value of VMD, $103 \mu \mathrm{m}$, and the highest values of $\%<100 \mu \mathrm{m}, 48 \%$. The atomizer Microspin produced the highest value of VMD, $198 \mu \mathrm{m}$, and the lowest $\%<100 \mu \mathrm{m}, 20 \%$. The VMD of the CBB atomizer was $174 \mu \mathrm{m}$, and it resulted in the lowest value of $\%<100 \mu \mathrm{m}, 17 \%$ and RS, 1.17 .

The only change of droplet size category from fine to medium was observed at the angle of 75 degrees, to the Microspin atomizer (Table 4). This atomizer produced VMD of $257 \mu \mathrm{m}$, differing statistically from the other atomizers.

TABLE 4. Treatments, atomizer rotational speed (rpm), means of droplet size statistics, percent of droplets smaller than $100 \mu \mathrm{m}$, relative span and droplet size spectrum classification, at the blade angle of 75 degrees. The flow rate and wind speed were $6 \mathrm{~L} \mathrm{~min}^{-1}$ and $180 \mathrm{~km} \mathrm{~h}^{-1}$, respectively.

\begin{tabular}{|c|c|c|c|c|c|c|c|}
\hline Treatment & $\mathrm{rpm}$ & DV10 & VMD & DV90 & $\%<100 \mu \mathrm{m}$ & $\mathrm{RS}$ & Category* \\
\hline & & & $-\mu \mathrm{m}$ & & $-\%-$ & & \\
\hline ASC & 2334 & $81 \mathrm{~B}$ & $206 \mathrm{D}$ & $360 \mathrm{CD}$ & $15 B$ & $1.35 \mathrm{BC}$ & Fine \\
\hline CBB & 2360 & $88 \mathrm{~A}$ & $231 \mathrm{~B}$ & 359CD & $12 \mathrm{C}$ & $1.17 \mathrm{D}$ & Fine \\
\hline Microbell & 1742 & $90 \mathrm{~A}$ & $225 \mathrm{C}$ & $390 \mathrm{~B}$ & $12 \mathrm{C}$ & $1.33 \mathrm{C}$ & Fine \\
\hline Microspin & 1780 & $91 \mathrm{~A}$ & $257 \mathrm{~A}$ & $469 \mathrm{~A}$ & $12 \mathrm{C}$ & $1.47 \mathrm{~A}$ & Medium \\
\hline Stol & 2161 & $69 \mathrm{D}$ & $174 \mathrm{E}$ & $298 \mathrm{E}$ & $20 \mathrm{~A}$ & $1.31 \mathrm{C}$ & Fine \\
\hline Travicar & 1488 & $74 \mathrm{C}$ & 208D & $358 \mathrm{D}$ & 17B & $1.37 \mathrm{BC}$ & Fine \\
\hline
\end{tabular}

* Category classification values are based on data generated using the guidelines established in ASAE S572.1. Means with the same letters in the column do not differ by Tukey's test at $\alpha=0.05$ level.

HOOPER \& SPURGIN (1995) evaluated the effect of angle blades and flow rate on the VMD of a solution composed by fenitrothion (ULV) sprayed by the AU5000 atomizer. At the flow rate of $5 \mathrm{~L} \mathrm{~min}^{-1}$ and at 45, 60 and 70 degrees, the rotational speed was 6770, 3800 and $2580 \mathrm{rpm}$, respectively, resulting in values of VMD equal to 63,118 and $159 \mu \mathrm{m}$, respectively. These results are compatible with those that were found on the present study.

Nevertheless, at 75 degrees the Stol atomizer resulted in a VMD of $174 \mu \mathrm{m}$ and $\%<100$ equal 20\%. At the same angle the Travicar and ASC atomizer showed values of VMD of 208 and $206 \mu \mathrm{m}$, respectively, and values of $\%<100 \mu \mathrm{m}$ of $17 \%$ and $15 \%$, respectively. Except to the CBB atomizer, all the other atomizers showed values of RS superior to 1.31 at the evaluated angles. At 75 degrees, the CBB atomizer showed value of RS of 1.17 .

In the wind tunnel, rotational speed can be held constant, whereas during actual applications, it varies according to atomizer position along the wing and the wind speed (TESKE. et al., 2006). 
Higher air speeds increase the rotational speed and cause more air shear across the atomizer, which can produce finer droplets, although the relative liquid to air velocity is an important consideration (TESKE, et al., 2005). Once the rotational speed is provided to the pilot by fitting an electronic application monitor on the airplane (HUANG et al., 2014), it can be used as a reference of droplet size to the evaluated atomizers.

This study provides results that help to understand the characteristics of aerial applications conducted in Brazil. These results may be considered as a reference before buying atomizers, and also help to plan strategies to reduce spray drift potential, as well as to increase the efficacy of the applications.

\section{CONCLUSIONS}

The blade angle of 75 degrees is recommended to decrease drift potential during spray applications of pesticides in Brazil compared with the blade angles of 45 or 60 degrees. The angle is not the only parameter to be considered, since atomizer model and brand influence the droplet size spectrum.

\section{ACKNOWLEDGMENTS}

This study was conducted during a scholarship supported by CAPES - Coordination for the Improvement of Higher Personnel Education. The authors also would like to thank the Pesticide Application Laboratory team, from The University of Nebraska-Lincoln, for their assistance.

\section{REFERENCES}

AL HEIDARY, M.; DOUZALS, J.P.; SINFORT, C.; VALLET, A. Influence of spray characteristics on potential spray drift of field crop sprayers: A literature review. Crop Protection, Amsterdam, v.63, p.120-130, set. 2014. Disponível em:

<http://www.sciencedirect.com/science/article/pii/S0261219414001604>. Acesso em: 8 out. 2015.

ANTUNIASSI, U. Evolution of agricultural aviation in brazil. Outlooks on Pest Management, Cambridgev.26, n.1, p.12-15, fev. 2015.

ANTUNIASSI, U.R.; VELINI, E.D.; OLIVEIRA, R.B.; OLIVEIRA, M.A.P.; FIGUEIREDO, Z. Systems of aerial spraying for soybean rust control. Engenharia Agrícola, Jaboticabal, v.31, n.4, p.695-703, 2011. Disponível em: <http://www.scielo.br/scielo.php?script=sci_arttext\&pid=S010069162011000400008\&lng=en\&nrm=iso\&tlng=en>. Acesso em: 25 jan. 2016.

ASAE/ASABE S572.1. Spray nozzle classification by droplet spectra. St Joseph, American Society of Agricultural Engineers, 2009.

BAYER, T.; COSTA, I.F.D.; LENZ, G.; ZEMOLIN, C.; MARQUES, L.N.; STEFANELO, M.S. Equipamentos de pulverização aérea e taxas de aplicação de fungicida na cultura do arroz irrigado. Revista Brasileira de Engenharia Agríclola e Ambiental, Campina Grande, v.15, n.2, p.192-198, 2011. Disponível em: <http://www.scielo.br/pdf/rbeaa/v15n2/v15n2a07>. Acesso em: 3 fev. 2016.

CHECHETTO, R.G.; ANTUNIASSI, U.R.; MOTA, A.A.B.; CARVALHO, F.K.; SILVA, A.C.A.; VILELA, C.M. Influence of spray nozzles and adjuvants in drift reduction potential in wind tunnel. Semina: Ciências Agrárias, Londrina, v.34, n.1, p.37-46, 2013. Disponível em: <http://www.cabdirect.org/abstracts/20133105686.html>. Acesso em: 3 nov. 2015.

CRAIG, I.P.; HEWITT, A.J.; TERRY, H. Rotary atomiser design requirements for optimum pesticide application efficiency. Crop Protection, Amsterdam, v.66, p.34-39, 2014. Disponível em: 〈http://linkinghub.elsevier.com/retrieve/pii/S026121941400266X〉. 
FERGUSON, J.C.; O'DONNELL C.C.; CHAUHAN, B.S.; ADKINS, S.W.; KRUGER, G.R.; WANG, R.; FERREIRA, P.H.U.; HEWITT, A.J. Determining the uniformity and consistency of droplet size across spray drift reducing nozzles in a wind tunnel. Crop Protection, Amsterdam, v.76, p.1-6, 2015. Disponível em:

<http://linkinghub.elsevier.com/retrieve/pii/S026121941530048X>.

FERGUSON, J.; HEWITT, A.J.; EASTIN, J.A.; CONNELL, R.J.; ROTEN, R.L.; KRUGER, G.R. Developing a comprehensive Drift Reduction Technology risk assessment scheme. Journal of Plant Protection Research, Poznán, v.54, n.1, p.78-84, 2014. Disponível em:

$<$ http://www.degruyter.com/view/j/jppr.2014.54.issue-1/jppr-2014-0013/jppr-2014-0013.xml>. Acesso em: 28 jan. 2016.

FRITZ, B.K.; HOFFMANN, W.C.; WOLF, R.E.; BRETTHAUER, S.; BAGLEY, W.E. Wind tunnel and field evaluation of drift from aerial spray applications with multiple spray formulations. Pesticide Formulations and Delivery Systems. 2012a. Disponível em:

<http://oai.dtic.mil/oai/oai?verb=getRecord\&metadataPrefix=html\&identifier=ADA578773>. doi: 10.1520/STP104403.

FRITZ, B.K.; HOFFMANN, W.C.; CZACZYKL, Z.; BAGLEY, W.E.; KRUGER, R.G.; HENRY, R. Measurement and classification methods using the ASAE S572.1 reference nozzles. Journal of Plant Protection Research, Poznán, v.52, n.4, p.447-457, 2012b. Disponível em: $<$ http://www.degruyter.com/view/j/jppr.2012.52.issue-4/v10045-012-0072-x/v10045-012-0072X.xml>.

GANDOLFO, M.A.; CARVALHO, F.K.; CHECHETTO, R.G.; GANDOLFO, U.D.; MORAES, E. D. Effect of working pressure at different spray nozzles on drift quantification in wind tunnel.

Engenharia Agrícola, Jaboticabal, v.34, n.1, p.66-73, fev. 2014. Disponível em:

$<$ http://www.scielo.br/scielo.php?script=sci_arttext\&pid=S0100-

69162014000100008\&lng=en\&nrm=iso\&tlng=en>. Acesso em: 26 jan. 2016.

HEWITT, A.J. Spray optimization through application and liquid physical property variables-I.

The Environmentalist, Lausanne, v.28, n.1, p.25-30, set. 2007. Disponível em: <http://link.springer.com/10.1007/s10669-007-9044-5>. Acesso em: 18 nov. 2015.

HILZ, E.; VERMEER, A.W.P. Spray drift review: The extent to which a formulation can contribute to spray drift reduction. Crop Protection, Amsterdam, v.44, p.75-83, 2013. Disponível em: <http://linkinghub.elsevier.com/retrieve/pii/S0261219412003006>.

HOFFMANN, W.C.; FRITZ, B.K.; BAGLEY, W.E.; GEDNALSKE, J. ELSIK, C.E. Determination of selection criteria for spray drift reduction from atomization data. Pesticide Formulation and Delivery Systems, West Conshohochen, n.32, p.65-79, set. 2013. Disponível em: <http://www.astm.org/doiLink.cgi?STP104454>. doi: 10.1520/STP104454.

HOOPER, G.H.S.; SPURGIN, P.A. Droplet size spectra produced by the atomization of a ULV formulation of fenitrothion with a Micronair AU5000 rotary atomizer. Crop Protection, Amsterdam, v.14, n.1, p.27-30, fev. 1995. Disponível em:

<http://www.sciencedirect.com/science/article/pii/026121949591108R>. Acesso em: 18 nov. 2015.

HUANG, Y.; ZHAN, W.; FRITZ, B.K.; THOMSON, S.J. Optimizing selection of controllable variables to minimize downwind drift from aerially applied sprays. Applied Engineering in Agriculture, St Joseph, v.28, n.3, p.307-314, 2012. Disponível em:

<http://elibrary.asabe.org/abstract.asp?aid=41487>. Acesso em: 3 fev. 2016.

HUANG, G.A.; BETAMAN, R.; MILLER, P. Aerial Application. In: MATTEWS, G.A.; BETAMAN, R.; MILLER, P. Pesticide application methods. 4ed. 2014. p.299-335.

OLIVEIRA, R.B.; ANTUNIASSI, U.R.; GANDOLFO, M.A. Spray adjuvant characteristics affecting agricultural spraying drift. Engenharia Agrícola, Jaboticabal, v.35, n.1, p.109-116, jan/fev. 2015. 
TESKE, M.E.; THISTLEH.W.H.; REARDON, R.C.; DAVIES, D.C.; CORMIER, G.; CAMERON, R.S.; LECLERC, M.Y; KARIPORT, A. Flight line variability in rotary atomizer drop size distribution. Journal of ASTM International, West Conshohocken, v.3, n.1, p.19-22, dez. 2006. Disponível em: <http://www.astm.org/DIGITAL_LIBRARY/JOURNALS/JAI/PAGES/JAI12922.htm>. Acesso em: 25 jan. 2016.

TESKE, M.E.; HEWITT, A.J.; MICKLE, R.E. The measurement of droplet size distributions from rotary atomizers. Pesticide Formulations and Applications Systems, Philadelphia, v.21, p.197209, 2001.

TESKE, M.E.; THISTLE, H.W.; HEWITT, A.J.; KIRK, I.W.; DEXTER, R.W.; GHENT, J.H. Rotary atomizer drop size distribution database. Transactions of the ASAE, St Joseph, v.48, n.3, p.917-921, 2005. Disponível em: <http://naldc.nal.usda.gov/naldc/catalog.xhtml?id=5503>. Acesso em: 18 nov. 2015. 